\title{
Biological Treatment for Greywater Reclamation
}

\author{
X. J. Chen ${ }^{1,2 *}$, Y. H. Wu ${ }^{1,2}$, S. Young ${ }^{1,2}$, W. W. Huang ${ }^{3}$, M. J. Palmarin ${ }^{1}$, and Y. Yao ${ }^{1,2}$ \\ ${ }^{1}$ Department of Environmental Systems Engineering, University of Regina, 3737 Wascana Parkway, Regina, Saskatchewan, S4S 0A2 Canada \\ ${ }^{2}$ Institute for Energy, Environment and Sustainable Communities, 240, 2 Research Drive, Regina, Saskatchewan, S4S 7H9 Canada \\ ${ }^{3}$ Faculty of Engineering \& Applied Science, Memorial University of Newfoundland, St. John's, Newfoundland, A1B 3X5 Canada
}

Received 3 February 2020; revised 1 March 2020; accepted 15 March 2020; published online 31 March 2020

\begin{abstract}
Greywater reclamation is generally recognized as a viable solution to mitigate the challenges caused by water scarcity, increasing wastewater production, and increasingly stringent wastewater discharge permits. Biological processes may provide lower capital and operating costs, and less sludge production, than comparable physicochemical processes. This paper provides a general overview of the biological treatment processes currently available for greywater reclamation, including: rotating biological contactors, sequencing batch reactors, anaerobic sludge blanket bioreactors, constructed wetlands, membrane bioreactors, and hybrid membrane bioreactors. The advantages, disadvantages, and limitations of each of these technologies were examined in detail. The challenges of using reclaimed greywater were also examined in relation to the long-term sustainability of greywater reclamation. On balance, membrane-based processes were found to be among the most promising technologies for decentralized greywater reclamation, due largely to the quality of their treated water and compact size.
\end{abstract}

Keywords: rotating biological contactor, sequencing batch reactor, anaerobic sludge blanket bioreactor, constructed wetland, membrane bioreactor, hybrid membrane bioreactor

\section{Introduction}

Over the past century, water shortages and polluted waterways have increasingly become serious environmental issues for many nations throughout the world (Wu et al., 1997; Weng et al., 2010; Tan et al., 2011). This has occurred due to an increase in both freshwater consumption and wastewater production (Maqsood et al., 2005; McBean, 2019). Greywater reclamation is generally recognized as a viable option to address these challenges (Huang et al., 1996; Cai et al., 2007). A domestic wastewater stream is typically composed of a mixture of greywater and blackwater (Murat Hocaoglu et al., 2010). The term greywater is used to describe wastewater free of faecal contaminants. Greywater is therefore primarily generated from most domestic wastewater sources with the exception of toilets. These sources include bathroom sinks, bathtubs, showers, laundry machines, and dishwashers (Ghaitidak and Yadav, 2013). Greywater mainly contains food particles, detergents, soap residues, oil/grease, and pathogens (Young and $\mathrm{Xu}, 2008$ ). The actual characteristics vary considerably from source to source, and are largely influenced by the lifestyle of the occupants of a given building, their location, and the surrounding climatic conditions (Oteng-Peprah et al., 2018). Greywater may account for up to $75 \%$ of all domestic wastewater produc-

* Corresponding author. Tel.: +1 3063378537

E-mail address: Chen240x@uregna.ca (X. J. Chen).

ISSN: 2663-6859 print/2663-6867 online

(C) 2020 ISEIS All rights reserved. doi:10.3808/jeil.202000027. tion (Jamrah et al., 2006; Leal et al., 2011). Recently, greywater has garnered much attention since it is less polluted than blackwater, available in large volumes, and offers a high potential for reuse (Li et al., 2010; Vuppaladadiyam et al., 2019).

In recent years, many studies have examined various physical, chemical, and biological processes for greywater reclamation (Yu et al., 2011; Chen et al., 2017; Chen et al., 2019; Zhang et al., 2019). Typical physical treatment processes may include coarse sand filtration, soil filtration, or membrane filtration, followed by disinfection (An et al., 2016; Chen et al., 2019; McBean et al., 2019). However, physical treatment processes alone are not sufficient to guarantee adequate reductions of dissolved organics, nutrients, or surfactants (Li et al., 2009; Ghunmi et al., 2011; Zhao et al., 2017). As such, their application is most effective in wastewater pre-treatment, and not as the primary treatment process for greywater reclamation. The chemical processes applied for greywater treatment may include coagulation, photocatalytic oxidation, ion exchange, and granular activated carbon (Li et al., 2004; Li et al., 2009; Ghunmi et al., 2011). Compared to physical processes, chemical processes may provide greater reductions of organic substances and turbidity, but may not achieve sufficient reductions to meet certain non-potable reuse standards (Li et al., 2009; Chen et al., 2018). Furthermore, the addition of chemicals creates secondary pollutants, which may ultimately complicate the design of the treatment train. In comparison, biological technologies are more suitable for greywater treatment by offering the advantages of lower costs, simpler operation, and easier maintenance. 
Membrane-based biological treatment technologies, such as a membrane bioreactor (MBR) or hybrid membrane bioreactor (HMBR), have small footprints, and can achieve good quality effluents without the production of secondary pollutants. Many biological treatment technologies have been developed and tested to achieve excellent results for greywater reclamation.

The objective of greywater reclamation is to produce a treated effluent of sufficient quality to be reused for a variety of non-potable water applications, including: toilet flushing, washing laundry, irrigation, washing windows and cars, recharging groundwater aquifers, and firefighting (Eriksson et al., 2002; Song et al., 2018). Many different types of biological treatment processes have been used to treat greywater, including: membrane bioreactors, hybrid membrane bioreactors, rotating biological contactors (RBC), sequencing batch reactors (SBR), anaerobic sludge blanket bioreactors (UASB), and constructed wetlands $(\mathrm{CW})$. These biological processes are reviewed and discussed in this paper. The advantages, disadvantages, and limitations of each of these technologies are examined in detail. In addition, the challenges and perspectives of biological greywater treatment are discussed in relation to the long-term sustainability of greywater reclamation.

\section{Treatment Methods}

\subsection{Membrane Bioreactor}

A membrane bioreactor describes any wastewater treatment process that combines biodegradation with membrane filtration, typically through the incorporation of microfiltration membranes within an aerated activated sludge bioreactor. MBRs have been regarded as an important technology for greywater treatment because of their consistent ability to remove high levels of contaminants and pathogens (Li et al., 2009; Palmarin and Young, 2019b; Wu, 2019). The main function of the membrane is to separate biosolids from the permeate during biological treatment. In doing so, it removes the need for a secondary clarifier and a return activated sludge stream. This retention of biosolids allows for a higher concentration of biomass to be held within the bioreactor (Wu, 2019). Consequently, the overall footprint of the system can be reduced.

In recent decades, many researchers have examined the use of MBRs for greywater reclamation. A submerged MBR from Zenon (membrane pore size $=0.1 \mu \mathrm{m}$ ) was studied by Merz et al. (2007) for the treatment of low-strength greywater from a sports and leisure club. The turbidity, chemical oxygen demand (COD), biochemical oxygen demand (BOD5), total Kjeldahl nitrogen (TKN), ammonia, total phosphorus (TP), linear alkylbenzene sulfonates (LAS), and faecal coliforms were reduced from $29 \mathrm{NTU}, 109 \mathrm{mg} / \mathrm{L}, 59 \mathrm{mg} / \mathrm{L}, 15.2 \mathrm{mg} / \mathrm{L}$, $11.8 \mathrm{mg} / \mathrm{L}, 1.6 \mathrm{mg} / \mathrm{L}, 299 \mu \mathrm{g} / \mathrm{L}$, and $1.4 \times 10^{5} / 100 \mathrm{~mL}$ in the influent, to $0.5 \mathrm{mg} / \mathrm{L}, 15 \mathrm{mg} / \mathrm{L}, 5 \mathrm{mg} / \mathrm{L}, 5.7 \mathrm{mg} / \mathrm{L}, 3.3 \mathrm{mg} / \mathrm{L}$, $1.3 \mathrm{mg} / \mathrm{L}, 10 \mu \mathrm{g} / \mathrm{L}$, and $68 / 100 \mathrm{~mL}$ in the effluent, respectively. The permeate flux ranged from 8 to $10 \mathrm{~L} / \mathrm{m}^{2} \mathrm{~h}$. The effluent did not exhibit any noticeable colour and odour. The detection of faecal coliforms in the permeate was attributed to accidental contamination of the treated water in the distribution system
(Merz et al., 2007). Young and Xu (2008) developed and tested a low-sludge discharge membrane bioreactor for greywater reclamation. This system was designed to operate at a high biomass concentration by reducing the sludge wasting rate. It was found that $95 \%$ of the anionic surfactants, and $90 \%$ of the $\mathrm{BOD}_{5}$ were removed when the system was operated at a hydraulic retention time (HRT) of $2.5 \mathrm{~h}$. In addition, the effluent ammonia and TKN concentrations were reduced to less than 1 $\mathrm{mg} / \mathrm{L}$ and $6 \mathrm{mg} / \mathrm{L}$, respectively. The effluent from this system was able to meet the unrestricted non-potable water reuse standard. Hu et al. (2011) studied synthetic greywater using four MBRs. In each case, a flat sheet membrane with a surface area of $120 \mathrm{~cm}^{2}$ was submerged within a $1.8 \mathrm{~L}$ container that was inoculated with activated sludge obtained from a local wastewater treatment plant. The MBRs achieved a BOD removal of $93 \%$, and a turbidity removal of $98 \%$. Faecal coliforms were not detected in the effluent due to the nominal pore size of the membranes, which were small enough to exclude these contaminants.

Bani-Melhem and Smith (2012) designed an integrated process consisting of an electro-coagulation (EC) unit and a submerged MBR for greywater treatment. This system reduced the turbidity to $4.1 \pm 2.3 \mathrm{FTU}(97 \%)$, the colour to $26 \pm 20 \mathrm{Pt}$ Co $(94 \%)$, the suspended solids to approximately $0 \mathrm{mg} / \mathrm{L}$ $(\sim 100 \%)$, and the total coliforms to less than $60 \mathrm{CFU} / 100 \mathrm{~mL}$ $(\sim 100 \%)$ in final effluent. The reduction of COD and phosphate were 89 and $94.3 \%$, respectively. However, only $77.8 \%$ of the ammonia nitrogen was removed. As such, further optimization of the electrolysis process may be required so as not to impede the biological treatment. Lamine et al. (2012) examined the practical performance of a submerged MBR for the treatment of low-strength greywater. A 17 L laboratory-scale bioreactor with a flat-plate microfiltration membrane (polyethylene; pore size $0.4 \mu \mathrm{m}$ ) was operated to treat the effluent from the showers of a student housing complex at the Tunis Agriculture University. Permeate was intermittently withdrawn at a constant transmembrane pressure induced by hydrostatic pressure. The system obtained a stable output with an excellent effluent quality in terms of COD, SS, and anionic surfactant levels $(20,<0.1$, and $0.025 \mathrm{mg} / \mathrm{L}$, respectively). In addition, faecal coliforms were undetected in the permeate.

Energy consumption accounts for a large proportion of the operating cost of an MBR. To reduce energy consumption, Ding et al. (2017) developed a low-pressure gravity-driven membrane bioreactor system for the treatment of greywater. The system was operated without any direct shear at the membrane surface and without any membrane cleaning or backflushing. The permeability stabilized at $20 \mathrm{~L} / \mathrm{m}^{2} \mathrm{~h}$ bar after approximately 50 days, with about a $95 \%$ total organic carbon (TOC) removal rate. The energy consumption of the MBR was $0.02 \sim 0.04 \mathrm{kWh} / \mathrm{m}^{3}$, which is substantially less than that of a normal MBR, and even less than that of a traditional activated sludge process (Ding et al., 2017). During the process of greywater treatment, oxygen is commonly provided via aeration for microorganism metabolism. It has been reported that aeration accounts for $70 \sim 80 \%$ of the energy consumption of greywater treatment (Sun et al., 2016). In order to reduce this cost, 
Atanasova et al. (2017) evaluated an MBR with an automatic air-scour control system for greywater reuse in hotels in the dry Mediterranean region. After optimization, the MBR could reduce more than $30 \%$ of the energy required for air scouring by using the automatic air-scour control system. It was also found that the MBR coped well with the high variability of the influent greywater characteristics, and provided a stable effluent quality. The COD removal efficiencies ranged from $80 \sim 95 \%$, and the COD concentration in the effluent was lower than 30 $\mathrm{mg} / \mathrm{L}$. The average removal rate for ammonia was $80.5 \pm$ $32.2 \%$, and the average pathogenremoval rate was $3 \sim 5 \log$.

Despite the ongoing technical progress and practical application of MBR-based treatment systems, membrane fouling continues to be a major challenge which hinders its long-term operation (Meng et al., 2017). Membrane fouling inevitably occurs during membrane filtration, leading to higher energy consumption and maintenance costs (Wu, 2019). Due to this challenge, it is critically important to understand membrane fouling mechanisms and to implement suitable membrane fouling control strategies to improve the competitiveness of MBR-based systems for greywater treatment.

To address membrane fouling, moving bed biocarriers may be added directly into the activated sludge of a conventional MBR, a configuration commonly referred to as a hybrid membrane bioreactor (HMBR). The biocarriers provide mechanical scouring of the membrane surface, which reduces the thickness of the cake layer and helps to restore permeability during operation (Deng et al., 2014; Kurita et al., 2016; Nguyen et al., 2016). The influence of the biocarriers on the characteristics of the sludge has also been shown to reduce fouling, in some instances, by up to $40 \%$ (Palmarin and Young, 2019b). Unlike a conventional MBR, the inclusion of biocarriers also permits the development of attached-growth bacteria, which increase the populations of both nitrifying and denitrifying bacteria within the bioreactor. As a consequence, total and ammonia nitrogen can be more efficiently removed during treatment (Palmarin and Young, 2019a). Compared to a conventional biological nutrients removal process (BNR), the HMBR may be implemented as a single completely-mixed bioreactor. This greatly simplifies the nitrogen removal process by removing the need for aerobic/anaerobic zone separation and return activated sludge. Since the cost of biocarriers is relatively small, the HMBR offers a compelling alternative to a conventional MBR, in terms of cost-effectiveness, compactness, and reliability.

\subsection{Rotating Biological Contactor}

A rotating biological contactor (RBC) is an attachedgrowth biological process that consists of one or more basins in which large closely spaced circular disks, mounted on horizontal shafts, rotate slowly through the wastewater (Ghaitidak and Yadav, 2013). As shown in Figures 1 and 2, a portion of each disk is partly submerged in the wastewater while a separate portion is exposed to the atmosphere. The wastewater is mixed by the constant rotation of the disks. The large surface area of each disk provides a habitat for biofilm bacteria to attach and propagate. Oxygen is transferred to the biofilm when the disks rise above the liquid surface. RBCs have been widely used due to their great process stability, easy maintenance, and low power consumption. The only energy required to aerate and mix an RBC is used to rotate the circular disks, and to overcome the friction of the disks as they move through the liquid (Waskar et al., 2012). The fixed biofilms ensure process stability with hydraulic load variations because the attached biomass cannot be washed out even if the flow rate increases (Cortez et al., 2008). With these advantages, the RBC exhibits excellent process control, and the capability of treating greywater with a wide range of flow rates and organic concentrations (Hassard et al., 2015).

Given these advantages, research and development has been ongoing for the use of RBCs in greywater treatment. Friedler et al. (2005) developed a system that incorporated an $\mathrm{RBC}$ with sand filtration and chlorination for the treatment of low-strength greywater. A fine screen preceded the RBC for the removal of solids greater than $1 \mathrm{~mm}$. The pilot plant successfully reduced 82,98 , and $96 \%$ of the TSS, turbidity, and BOD, respectively. Eriksson et al. (2007) examined a pilot RBC for the treatment of bathroom greywater from 84 housing units within an apartment block. The reclaimed water was then reused for toilet flushing. The plant consisted of a primary settling/equalization basin, three RBCs in series, a secondary clarifier, a sand filter, and finally a disinfection process using ultraviolet (UV) light. Their study showed that the five selected paraben biocides (methyl-, ethyl-, propyl-, butyl-, and iso-butyl- esters of parahydroxy benzoicacid) were effectively removed by the treatment plant, showing that the microorganisms had adapted to the parabens as a carbon source for their growth. The removal efficiencies of the selected biocides ranged from $87 \%$ to $99 \%$, which were even higher than the removal efficiencies of the composite parameters (COD, BOD, and TOC).

Baban et al. (2010) examined two RBCs to assess their potential for greywater reclamation. In this study, the RBCs were operated concurrently in order to perform a conformity assessment of the effluent for reuse, and to determine the biofilm kinetics within the RBC treatment systems. About $85 \%$ of the COD and $75 \%$ of the TKN were removed from the influent wastewater. The zero-order kinetic rate constant was determined to be $5.7 \pm 1.5$. A UV light was used to disinfect the treated greywater. The efficiency, operational ease, reliability, and personnel requirements of the RBC systems were compared against alternative greywater treatment processes. It was concluded that an RBC may be effectively used for greywater treatment, and that the treated water could be reused for toilet flushing purposes after disinfection (Baban et al., 2010). However, filtration was also recommended to remove any particles that may detach from the biofilm. Pathan et al. (2011) examined the use of a single-stage RBC to treat sink and shower greywater from a boy's hostel at the University of Sindh, Jamshoro, Pakistan. In this study, the disks were spun at a rate of $1.7 \mathrm{rpm}$. Approximately $40 \%$ of the disks were immersed in the greywater. This configuration was able to remove up to $53 \%$ of the $\mathrm{BOD}_{5}$ and $60 \%$ of the COD in the greywater.

In recent years, new developments have also been 

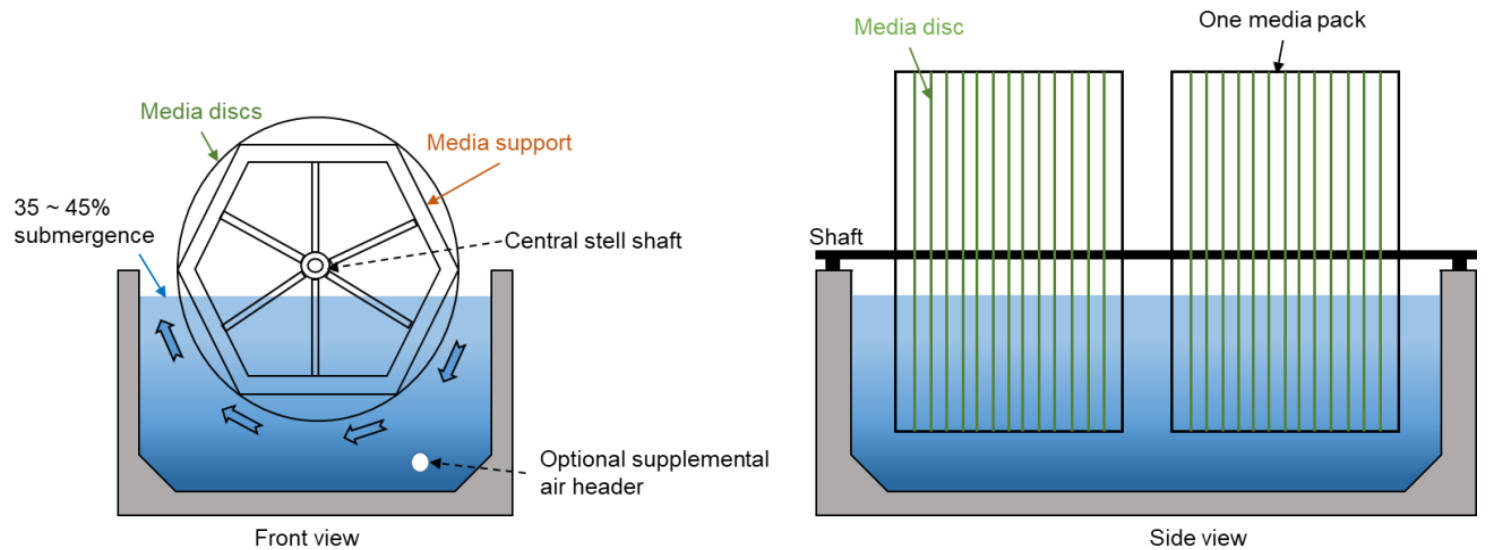

Figure 1. Diagram of a typical RBC.
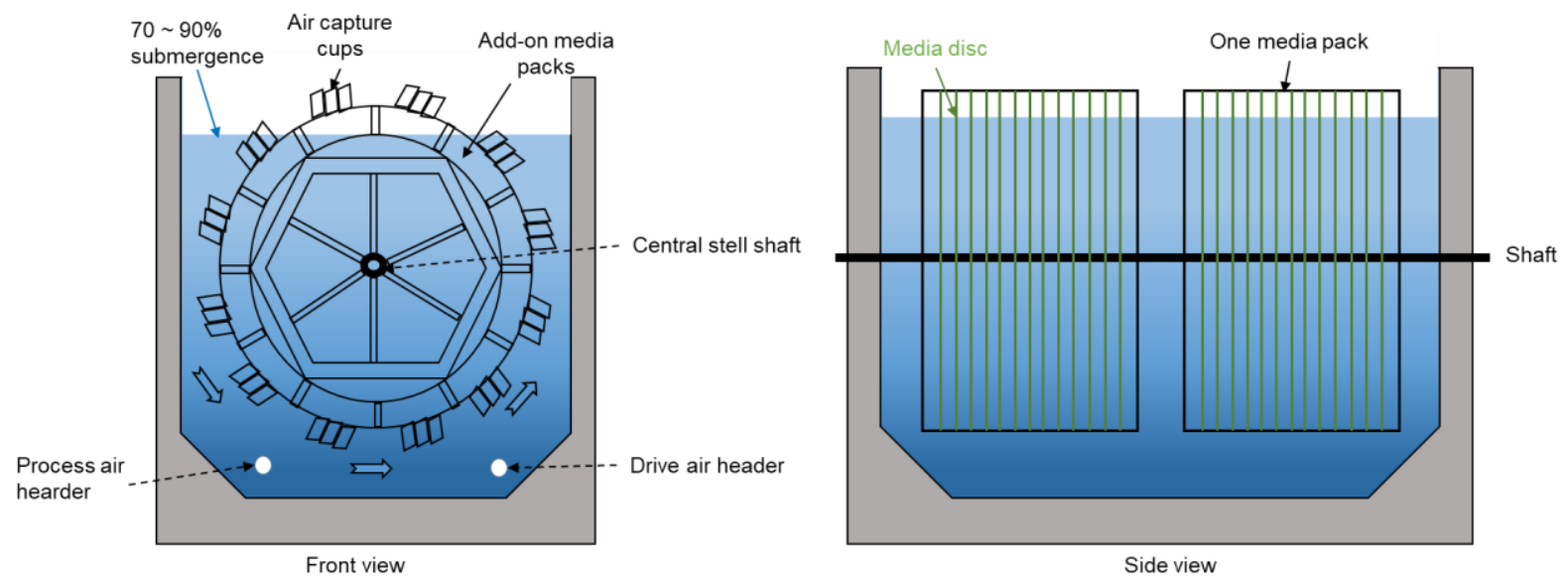

Figure 2. Diagram of a submerged RBC.

achieved to decrease the power consumption, reduce investment costs, and improve the efficiency of RBC systems for greywater treatment. Tabraiz et al. (2016) carried out a study to evaluate the suitability of polyethylene foam as the disk material for an RBC. A pilot-scale model of the RBC was constructed to treat domestic sewage under different rotation speeds and submergence. Optimum values for rotation speed and submergence were found to be $40 \%$ and $5 \mathrm{rpm}$, respectively. Under these conditions, the BOD and COD removal rates were 85.7 and $67.6 \%$, respectively. The cost of using polyethylene foam as a disk material was $\$ 0.38 \mathrm{USD} / \mathrm{m}^{2}$, while the cost of a conventional polystyrene disk was estimated to be $\$ 1.91 \mathrm{USD} / \mathrm{m}^{2}$. Due to the lesser weight of the polyethylene foam, the energy consumption of the newly proposed material was $26 \mathrm{kWh} / \mathrm{m}^{3} / y e a r$, which was much lower than that of the polystyrene material $\left(96.6 \mathrm{kWh} / \mathrm{m}^{3} /\right.$ year) (Tabraiz et al., 2016). Besides, no wear and tear was found on the polyethylene foam disks after a continuous run of 90 day. Zha et al. (2018) utilized a novel multi-stair waterwheel driven RBC to save land use and energy consumption, which was combined with an anoxic filter for post-treatment. The system was design to treat a mixture of digested blackwater and raw greywater. The system achieved adequate COD, TN, and ammonia removal efficiencies, but poor TP removal after 10 weeks of operation at the optimum parameters (Zha et al., 2018). When running at a $150 \%$ reflux ratio and at a $1 \mathrm{~h}$ HRT (per stair), the removal efficiencies for COD, TN, ammonia, and TP were $88 \pm 2,52 \pm 4,88 \pm 2$, and $34 \pm 7 \%$, respectively.

\subsection{Sequencing Batch Reactor}

A sequencing batch reactor (SBR) refers to a single reactor activated sludge treatment process staged in five steps: fill, react, settle, decant, and idle. These five steps are shown in Figure 3. An SBR performs biological treatment and secondary clarification within a single reactor using a time-controlled sequence. Consequently, they are used frequently in small communities. SBRs are well-suited for the treatment of greywater under low or intermittent flow conditions ( $\leq 5$ MGD) (EPA, 1999). In comparison to a conventional activated sludge process, SBRs have the advantages of operational flexibility and control, a smaller footprint, and a lower capital cost through the elimination of a secondary clarifier and its associated equipment (Singh and Srivastava, 2011). However, SBRs require a 
higher level of sophistication in terms of timing and controls, especially for large-scale systems (Kassab et al., 2010). Consequently, these systems require a relatively high level of maintenance due to the sophistication of their control systems.

As SBR systems continue to improve, their use has been investigated for the treatment of greywater. Krishnan et al. (2008) investigated the treatment of greywater from the kitchens of seven residential houses in Serdang, Selangor, Malaysia, using an SBR. The reactor had a $0.37 \mathrm{~m}^{2}$ bottom with a total liquid depth of $0.68 \mathrm{~m}$, and an operating volume of $82 \mathrm{~L}$. The COD and BOD removal rates were $>90 \%$ for both nutrientdeficient and nutrient-spiked dark greywater. Hernandez et al. (2010) operated an aerobic SBR for the treatment of highstrength household greywater. During this experiment, $90 \%$ of the COD removal was achieved at an HRT of $12 \mathrm{~h}$ and a temperature of $32 \pm 3{ }^{\circ} \mathrm{C}$. Under these conditions, the sludge yield was only $0.12 \mathrm{~g}$ volatile suspended solids (VSS)/g COD. It was also found that $97 \%$ of the anionic surfactants were eliminated by the aerobic SBR. These results indicate that aerobic SBRs may be a suitable process for greywater treatment (Hernández Leal et al., 2010). He et al. (2011) tested 13 lab-scale SBRs for low-strength greywater, which consisted predominately of bathing products (shampoos and soaps). Each SBR had a working volume of $2 \mathrm{~L}$. Aeration was provided at a rate of $1.2 \mathrm{~L} / \mathrm{min}$. The results showed that the BOD/COD ratio of the treated water was less than 0.2 after treatment, with $95 \%$ of the organic compounds degraded within 28 days.

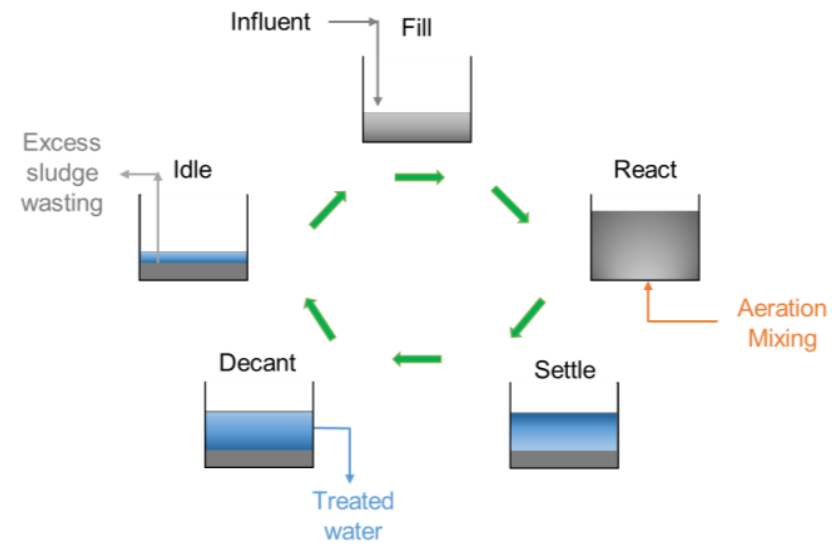

Figure 3. Diagram of a typical SBR.

Rojas-Z et al. (2017) studied the effects of greywater composition and specific organic loading rate on the development of granular biomass within an SBR. It was found that the greywater could support the growth of granular biomass with a sludge volume index of $98 \mathrm{~mL} / \mathrm{g}$, and a zone settling velocity of $13 \mathrm{~m} / \mathrm{h}$. The SBR was able to achieve a COD removal efficiency of $>80 \%$. It was also found that a reduction in the organic loading rate induced an improvement in the biomass settling properties, since filamentous microorganisms were reduced in the granules' structure. To maintain high-operational efficiency, granular biomass with high conversion rates and good settling properties should therefore be developed within the SBR. Operating at a low organic loading rate also enables the SBR to better handle the inherent variability in the composition of real greywater (Rojas-Z et al., 2017). SBRs may also implement biofilm carriers in place of suspended sludge, a configuration commonly referred to as a sequencing batch biofilm reactor. Tombola et al. (2019) utilized recycled corrugated wire hose cover as an alternative and low-cost carrier in a sequencing batch biofilm reactor for greywater treatment. This SBR was effective in removing $86.5 \%$ of the COD, $98.4 \%$ of the ammonia, and $71.4 \%$ of the TN from the greywater. These removal efficiencies were comparable to SBR systems utilizing commercial carriers.

\subsection{Upflow Anaerobic Sludge Blanket}

The upflow anaerobic sludge blanket (UASB) bioreactor is the most widely and successfully used high-rate anaerobic system for several types of greywater treatment (Chong et al., 2012). It consists of two parts: a cylindrical or rectangular column, and a gas-liquid-solid separator (Lettinga and Hulshoff Pol, 1991). As shown in Figure 4, wastewater enters the UASB bioreactor from the bottom and flows upwards towards the top of the column. As the water flows upwards, the soluble organic compounds in the wastewater are converted to biogas via anaerobic degradation. An immersed gas-liquid-solid separator is used to separate the biogas and sludge brought to the surface by entrapped bubbles (Chong et al., 2012). A UASB bioreactor can retain a high concentration of active suspended biomass with simple and low-cost operation (Ghaitidak and Yadav, 2013). However, UASB bioreactors typically require long solid retention times, and a long start-up period. Consequently, the risk of insufficient organic matter removal, and the presence of pathogens in the final effluent are increased (Chong et al., 2012). If this occurs, then the effluent may not meet the standards required for discharge or reuse.

Elmitwalli and Otterpohl (2007) operated a UASB at ambient temperature for mixed greywater treatment. While operating the UASB at HRTs of $8 \sim 20 \mathrm{~h}, 31 \sim 41 \%$ of the total COD, $24 \sim 36 \%$ of the TN, and $10 \sim 24 \%$ of the TP were removed. Later, Elmitwalli and R. Otterpohl (2011) ran a similar experiment, but increased the operating temperature to $30^{\circ} \mathrm{C}$. The results showed that after increasing the temperature, 52 $64 \%$ of the COD could be removed. Hernandez Leal et al. (2010) treated greywater from 32 houses in the DeSaR demonstration project in Sneek, Netherlands, using a 5 L UASB. However, this system resulted in a COD removal of only $51 \%$. The low removal efficiency may have been caused by the high concentration of anionic surfactants in the influent $(43.5 \mathrm{mg} / \mathrm{L})$, and by a reduced removal of the colloidal fraction of the COD in the UASB bioreactor.

The poor removal efficiencies of both organic substances and surfactants make UASB processes typically unsuitable for greywater recycling. As such, efforts have been put forth to further improve the UASB process. Ozgun et al. (2015) incorporated a membrane into a lab-scale UASB system for effluent extraction. The impact of the membrane on the treatment of high-strength greywater was then investigated. It was found 
that the membrane caused fine particles to accumulate within the bioreactor, and also caused a decrease in extracellular polymeric substances. These effects caused a reduction in sludge settleability (Ozgun et al., 2015). The decrease in sludge settleability increased sludge washout, and increased the COD and TSS in the UASB effluent. It was also found that the microbial community indices increased in both richness and evenness in the sludge after the membrane was added. Abdel-Shafy et al. (2019) proposed a system containing a UASB to treat greywater with detergents, phosphates, and oil and grease. The UASB effluent showed high removal rates of oil and grease, $\mathrm{BOD}_{5}, \mathrm{COD}, \mathrm{TP}$, and TKN, with values ranging $60 \sim 84 \%$. The UASB effluent was further treated using effective microorganism (EM) within a continuously aerated system. After this treatment, more than $70 \%$ of the contaminants were eliminated. The final effluent successfully reached the permissible limits for unrestricted reuse, according to the WHO and US EPA regulations (Abdel-Shafy et al., 2019).

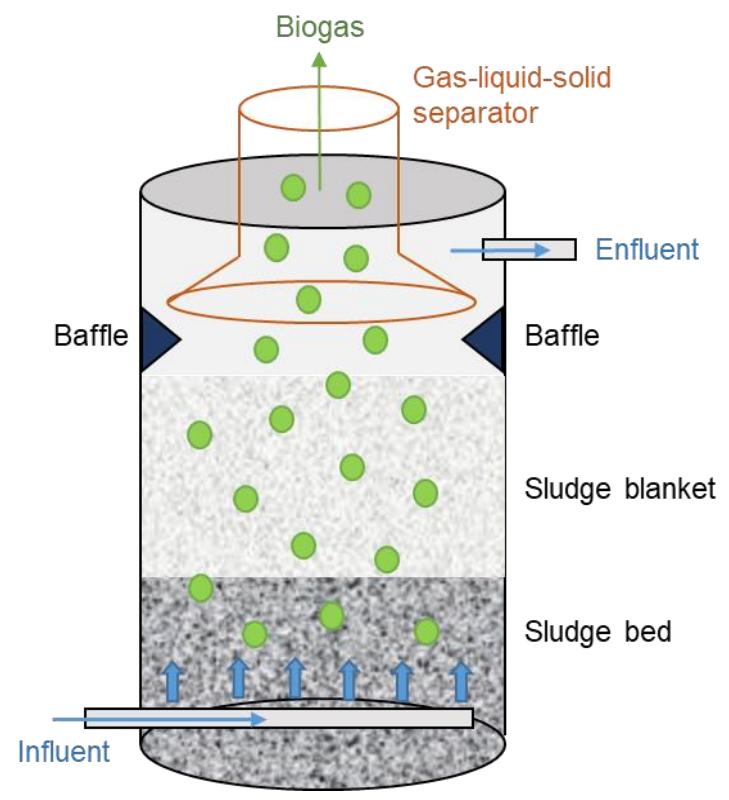

Figure 4. Diagram of a typical UASB bioreactor.

\subsection{Constructed Wetland}

A constructed wetland $(\mathrm{CW})$ treatment system utilizes wetland plants, soils, and associated microorganisms to remove contaminants from wastewater (Ghaitidak and Yadav, 2013). It has been considered to be one of the most environmentally friendly and cost-effective technologies for greywater treatment (Li et al., 2009). CW can remove contaminants such as BOD, suspended solids, metals (including cadmium, chromium, iron, lead, manganese, selenium, and zinc), and toxic organics from the wastewater. The removal rates of these processes depend on many factors, such as the surface loading rate, and the availability of electron acceptors (Halalsheh et al., 2008). In a study conducted by Gross et al. (2007), a recycled vertical-flow $\mathrm{CW}$ was used to treat high-strength mixed greywater. The TSS, $\mathrm{BOD}_{5}, \mathrm{COD}, \mathrm{TN}$, TP, anionic surfactants, bo- ron, and faecal coliforms were significantly reduced by 98,99 , $81,69,71,92,65$, and 99\%. Saumya et al. (2015) developed a root zone method of construction and evaluated a prototype wetland system for greywater treatment. The system utilized Heliconia angusta. Various greywater parameters, such as $\mathrm{COD}, \mathrm{BOD}_{5}$, residual chlorine, TSS, TDS, turbidity, indole producing faecal coliforms, as well as several heavy metals, showed a significant reduction. Ramprasad and Philip (2016) conducted a study to compare the performances of a pilot-scale horizontal (HFCW) and vertical subsurface flow constructed wetland (VFCW). The systems were designed for the removal of organics, nutrients, bacterial contamination, and emerging contaminants from greywater. Data was collected over a year to study the effect of several operating con- ditions, such as the hydraulic retention time, external organic loading rate, and the change of seasons on the performances of each system. The VFCW was marginally more efficient at treating the pollutants in comparison to the HFCW system. The removal efficiencies of certain emerging contaminants (sodium dodecyl sulphate (SDS), propylene glycol (PG), and trimethy- lamine (TMA)) were 89,95 , and $98 \%$, respectively. In the case of the HFCW, the removal efficiencies were 85,90 , and $95 \%$ for the SDS, PG, and TMA, respectively (Ramprasad and Philip, 2016).

However, the effluent from constructed wetlands cannot reliably meet microbiological standards for reuse. In order to address this issue, many studies have been carried out to improve the pathogen removal ability of constructed wetlands for greywater treatment (Wu et al., 2016). Sklarz et al. (2009) examined the use of a small-scale recirculating VFCW for the treatment of greywater. The treated water was designed to be reused for urban landscape irrigation. Two systems were operated with and without a soil-plant component and with various recirculation flow rates (RFR) and treatment times. At an RFR of $4.5 \mathrm{~m}^{3} / \mathrm{h}$ and a treatment time of $12 \mathrm{~h}$, the average $\mathrm{BOD}_{5}$ and TSS concentrations in the treated effluent were 5 and $10 \mathrm{mg} / \mathrm{L}$, respectively, for the system without a soil-plant component. Furthermore, a kinetic analysis showed that a treatment time of only $6 \mathrm{~h}$ was sufficient to achieve the required effluent quality for urban landscape irrigation. The addition of the soil-plant component, which necessitated a reduction in the RFR, caused no changes in the effluent quality, and its effect on treatment performance was not determined. In all operational modes, counts of $E$. coli were reduced from $10^{6}$ to $10^{3} \mathrm{CFU} / 100 \mathrm{~mL}$. A further reduction to $<10 \mathrm{CFU} / 100 \mathrm{~mL}$ was achieved following UV disinfection (Sklarz et al., 2009). The results indicated that the recirculating VFCW produced a high-quality effluent, and could treat greywater with a potential organic loading rate of over $120 \mathrm{~g}$ BOD $5 \mathrm{~m}^{-2} \mathrm{~d}^{-1}$.

Ramprasad et al. (2017) developed a green rooftop water recycling system (GROW) to remove chemical and microbial contaminants from greywater. The performance of the GROW system was monitored for 1.5 years while it treated greywater from the Krishna Student Hostel in IIT Madras. The flow rates were set as 62, 70, 82,100, and $120 \mathrm{~L} /$ day, respectively, with an HRT of $0.7 \sim 1.3$ days. The results showed that the removal efficiency for faecal coliforms was up to $91.4 \%$, and that the removal efficiencies for all of the chemical contaminants were 
Table 1. Biological Technologies for Greywater Reclamation

\begin{tabular}{|c|c|c|c|c|c|c|c|c|c|c|c|c|c|}
\hline \multirow[t]{2}{*}{ Reference } & \multirow[t]{2}{*}{ Technology } & \multicolumn{2}{|c|}{ TSS (mg/L) } & \multicolumn{2}{|c|}{ Turbidity (NTU) } & \multicolumn{2}{|c|}{$\mathrm{COD}(\mathrm{mg} / \mathrm{L})$} & \multicolumn{2}{|c|}{ BOD (mg/L) } & \multicolumn{2}{|c|}{$\mathrm{TN}(\mathrm{mg} / \mathrm{L})$} & \multicolumn{2}{|c|}{$\mathrm{TP}(\mathrm{mg} / \mathrm{L})$} \\
\hline & & In & Out & In & Out & In & Out & In & Out & In & Out & In & Out \\
\hline $\begin{array}{l}\text { Friedler et al. } \\
(2005)\end{array}$ & $\begin{array}{l}\text { Screen }+ \\
\text { RBC }\end{array}$ & 43 & 7.9 & 33 & 0.61 & 158 & 40 & 50 & 2.3 & ND & ND & 4.8 & 2.0 \\
\hline $\begin{array}{l}\text { Baban et al. } \\
(2010)\end{array}$ & $\mathrm{RBC}$ & 79 & 11 & 103 & 6 & 214 & 33 & 119 & 7 & 8 & 2.3 & 9.8 & ND \\
\hline $\begin{array}{l}\text { Pathan AA et } \\
\text { al. (2011) }\end{array}$ & $\mathrm{RBC}$ & 154 & $\begin{array}{l}137.5 \\
\pm 30.6\end{array}$ & ND & ND & $\begin{array}{l}146.1 \\
\pm 49.1\end{array}$ & $\begin{array}{l}57.9 \\
\pm 26\end{array}$ & $\begin{array}{l}56 \\
\pm 17\end{array}$ & $\begin{array}{l}26.46 \\
\pm 12.96\end{array}$ & ND & ND & ND & ND \\
\hline $\begin{array}{l}\text { Pariente et al. } \\
\text { (2013) }\end{array}$ & $\begin{array}{l}\mathrm{CWHPO}+ \\
\mathrm{RBC}\end{array}$ & ND & ND & $\begin{array}{l}12.0 \\
\pm 1.5\end{array}$ & $\begin{array}{l}1.6 \\
\pm 1.3\end{array}$ & $\begin{array}{l}250 \\
\pm 25\end{array}$ & $\begin{array}{l}56.0 \\
\pm 6.0\end{array}$ & ND & ND & $\begin{array}{l}57.0 \\
\pm 15.0\end{array}$ & $\begin{array}{l}39.0 \\
\pm 11.0\end{array}$ & ND & ND \\
\hline $\begin{array}{l}\text { Zha et al. } \\
\text { (2018) }\end{array}$ & $\begin{array}{l}\text { Anoxic filter } \\
+ \text { mswdRBCs }\end{array}$ & ND & ND & ND & ND & $\begin{array}{l}111.8 \\
\pm 12.63\end{array}$ & $\begin{array}{l}56.4 \\
\pm 7.2\end{array}$ & ND & ND & $\begin{array}{l}31.86 \\
\pm 2.45\end{array}$ & $\begin{array}{l}18.88 \\
\pm 1.63\end{array}$ & $\begin{array}{l}4.9 \\
\pm 0.7\end{array}$ & $\begin{array}{l}3.6 \\
\pm 0.56\end{array}$ \\
\hline $\begin{array}{l}\text { Krishnan et } \\
\text { al. (2008) }\end{array}$ & SBR & 130 & $<10$ & ND & ND & 630 & 31.5 & 370 & 19.2 & 11.8 & 1.5 & 4.5 & 0.7 \\
\hline $\begin{array}{l}\text { Hernandez et } \\
\text { al. (2010) }\end{array}$ & $\begin{array}{l}\text { SBR, SRT = } \\
378 \mathrm{~d}\end{array}$ & ND & ND & ND & ND & 827 & 100 & ND & ND & 29.9 & 26.5 & 8.5 & 5.8 \\
\hline $\begin{array}{l}\text { Lim et al. } \\
\text { (2011) }\end{array}$ & $\begin{array}{l}\text { MB-SBRs + } \\
8 \%(\mathrm{v} / \mathrm{v}) \text { PU }\end{array}$ & ND & ND & ND & ND & $\begin{array}{l}140 \\
\pm 20\end{array}$ & $\begin{array}{l}30 \\
\pm 10\end{array}$ & ND & ND & $\begin{array}{l}20 \\
\pm 2\end{array}$ & $\begin{array}{l}3 \\
\pm 1\end{array}$ & ND & ND \\
\hline $\begin{array}{l}\text { Li et al. } \\
\text { (2019) }\end{array}$ & $\begin{array}{l}\text { MB-SBRs + } \\
20 \%(\mathrm{v} / \mathrm{v}) \mathrm{LS}\end{array}$ & ND & ND & ND & ND & 50 & 11 & ND & ND & ND & ND & ND & ND \\
\hline $\begin{array}{l}\text { Elmitwalli et } \\
\text { al. (2007) }\end{array}$ & UASB & ND & ND & ND & ND & 681 & 470 & ND & ND & 27.1 & 20.6 & 9.9 & 7.5 \\
\hline $\begin{array}{l}\text { Hernandez } \\
\text { Leal et al. } \\
\text { (2010) }\end{array}$ & $\begin{array}{l}\text { UASB, HRT } \\
=12 \mathrm{~h}, \text { SRT }= \\
392 \mathrm{~d}\end{array}$ & ND & ND & ND & ND & $\begin{array}{l}833 \\
\pm 188\end{array}$ & 249 & ND & ND & $\begin{array}{l}41.2 \\
\pm 27.2\end{array}$ & $\begin{array}{l}34.0 \\
\pm 17.0\end{array}$ & $\begin{array}{l}6.6 \\
\pm 2.7\end{array}$ & $\begin{array}{l}5.3 \\
\pm 1.5\end{array}$ \\
\hline $\begin{array}{l}\text { Elmitwalli, T. } \\
\text { and R. } \\
\text { Otterpohl, } \\
\text { (2011) }\end{array}$ & $\begin{array}{l}\text { UASB, } \mathrm{T}= \\
30^{\circ} \mathrm{C}, \mathrm{HRT}= \\
16 \mathrm{~h}\end{array}$ & ND & ND & ND & ND & $\begin{array}{l}618 \\
\pm 130\end{array}$ & $\begin{array}{l}222 \\
\pm 44\end{array}$ & ND & ND & $\begin{array}{l}21.6 \\
\pm 3.3\end{array}$ & $\begin{array}{l}11.2 \\
\pm 2.16\end{array}$ & $\begin{array}{l}9.9 \\
\pm 0.3\end{array}$ & $\begin{array}{l}7.4 \\
\pm 0.36\end{array}$ \\
\hline $\begin{array}{l}\text { Ozgun et al. } \\
(2015)\end{array}$ & $\begin{array}{l}\text { UASB + } \\
\text { AnMBR }\end{array}$ & $\begin{array}{l}230 \\
\pm 25\end{array}$ & 0.5 & ND & ND & $\begin{array}{l}530 \\
\pm 30\end{array}$ & $\begin{array}{l}42.0 \\
\pm 4.4\end{array}$ & ND & ND & $\begin{array}{l}54.0 \\
\pm 5.2\end{array}$ & 57.0 & $\begin{array}{l}12.0 \\
\pm 0.8\end{array}$ & 11.8 \\
\hline $\begin{array}{l}\text { Gross et al. } \\
\text { (2007) }\end{array}$ & $\begin{array}{l}\text { Constructed } \\
\text { wetland }\end{array}$ & 158 & 3 & ND & ND & 839 & 157 & 466 & 0.7 & 34.3 & 10.8 & 22.8 & 6.6 \\
\hline $\begin{array}{l}\text { Sklarz et al. } \\
\text { (2009) }\end{array}$ & $\begin{array}{l}\text { Constructed } \\
\text { wetland }\end{array}$ & 90 & 10 & ND & ND & 270 & 40 & 120 & 5 & 43 & 31 & ND & ND \\
\hline $\begin{array}{l}\text { Saumya et al. } \\
\text { (2015) }\end{array}$ & SFCW & 13.3 & 5.1 & 161.3 & 12.7 & 579 & 349 & 290 & 87 & ND & ND & ND & ND \\
\hline $\begin{array}{l}\text { Ramprasad } \\
\text { and Philip, } \\
\text { (2016) }\end{array}$ & HFCW & $\begin{array}{l}240 \sim \\
320\end{array}$ & $28 \pm 12$ & ND & ND & $\begin{array}{l}216 \sim \\
264\end{array}$ & $\begin{array}{l}16.0 \\
\pm 8.0\end{array}$ & $\begin{array}{l}72 \sim \\
120\end{array}$ & $\begin{array}{l}10.0 \\
\pm 4.0\end{array}$ & $\begin{array}{l}17 \sim \\
28.82\end{array}$ & $\begin{array}{l}0.82 \\
\pm 0.22\end{array}$ & $\begin{array}{l}2.9 \sim \\
3.84\end{array}$ & $\begin{array}{l}0.1 \\
\pm 0.19\end{array}$ \\
\hline $\begin{array}{l}\text { Ramprasad } \\
\text { and Philip, } \\
\text { (2016) }\end{array}$ & VFCW & $\begin{array}{l}240 \sim \\
320\end{array}$ & $16 \pm 10$ & ND & ND & $\begin{array}{l}216 \sim \\
264\end{array}$ & $\begin{array}{l}8.0 \\
\pm 8.0\end{array}$ & $\begin{array}{l}72 \sim \\
120\end{array}$ & $\begin{array}{l}5.6 \\
\pm 6.0\end{array}$ & $\begin{array}{l}17 \sim \\
28.82\end{array}$ & $\begin{array}{l}0.22 \\
\pm 0.32\end{array}$ & $\begin{array}{l}2.9 \sim \\
3.8\end{array}$ & $\begin{array}{l}0.1 \\
\pm 0.18\end{array}$ \\
\hline $\begin{array}{l}\text { Ramprasad et } \\
\text { al. (2017) }\end{array}$ & $\mathrm{CW}$ & $\begin{array}{l}240 \sim \\
280\end{array}$ & $\begin{array}{l}20.16 \sim \\
23.52\end{array}$ & ND & ND & $\begin{array}{l}216 \sim \\
320\end{array}$ & $\begin{array}{l}16 \sim \\
24\end{array}$ & $\begin{array}{l}68 \sim \\
120\end{array}$ & $\begin{array}{l}6.26 \sim \\
11.04\end{array}$ & $\begin{array}{l}17 \sim \\
28.82\end{array}$ & $\begin{array}{l}1.411 \sim \\
2.39\end{array}$ & $\begin{array}{l}2.9 \sim \\
3.84\end{array}$ & $\begin{array}{l}0.4 \sim \\
0.46\end{array}$ \\
\hline $\begin{array}{l}\text { Lamine et al. } \\
\text { (2012) }\end{array}$ & MBR & $\begin{array}{l}33.0 \\
\pm 16\end{array}$ & $\mathrm{ND}$ & ND & ND & $\begin{array}{l}164 \\
\pm 59\end{array}$ & $\begin{array}{l}20.8 \\
\pm 5.8\end{array}$ & $\begin{array}{l}97.3 \\
\pm 32\end{array}$ & $\begin{array}{l}12.3 \\
\pm 2.5\end{array}$ & ND & ND & ND & ND \\
\hline $\begin{array}{l}\text { Bani-Melhem } \\
\text { and Smith, } \\
\text { (2012) }\end{array}$ & $\begin{array}{l}\text { MBR+ } \\
\text { electro- } \\
\text { coagulation }\end{array}$ & 78 & ND & 133 & $\begin{array}{l}4.1 \\
\pm 2.3\end{array}$ & 463 & $\begin{array}{l}51 \\
\pm 49\end{array}$ & ND & ND & ND & ND & 0.53 & $\begin{array}{l}0.03 \\
\pm 0.02\end{array}$ \\
\hline $\begin{array}{l}\text { Young and } \\
\mathrm{Xu},(2008)\end{array}$ & $\begin{array}{l}\text { MBR SRT = } \\
48 \mathrm{~d}\end{array}$ & 75 & 3.9 & ND & ND & 106.3 & 7.8 & 65.6 & 3 & 8.3 & 4.23 & 2.8 & 0.43 \\
\hline $\begin{array}{l}\text { Merz et al. } \\
(2007)\end{array}$ & MBR & ND & ND & 29 & 0.5 & 109 & 15 & 59 & 4 & 15.2 & 5.7 & 1.6 & 1.3 \\
\hline $\begin{array}{l}\text { Song et al. } \\
\text { (2018) }\end{array}$ & AF-MBR & ND & ND & $\begin{array}{l}21.9 \sim \\
98.1\end{array}$ & $\begin{array}{l}0 \sim \\
0.98\end{array}$ & $\begin{array}{l}104.4 \sim \\
262.7\end{array}$ & $\begin{array}{l}2.1 \sim \\
5.25\end{array}$ & ND & ND & $\begin{array}{l}47.1 \sim \\
84.7\end{array}$ & $25 \sim 30$ & $\begin{array}{l}4.4 \sim \\
12.5\end{array}$ & $\begin{array}{l}0.88 \sim \\
2.5\end{array}$ \\
\hline $\begin{array}{l}\text { Li et al. } \\
\text { (2019) }\end{array}$ & $\mathrm{A}_{2} \mathrm{O}-\mathrm{MBR}$ & ND & ND & ND & ND & $\begin{array}{l}350 \sim \\
600\end{array}$ & $\begin{array}{l}27.7 \\
\pm 9.3\end{array}$ & ND & ND & $\begin{array}{l}42 \sim \\
77\end{array}$ & $\begin{array}{l}13.0 \\
\pm 1.8\end{array}$ & $\begin{array}{l}4.0 \sim \\
6.0\end{array}$ & $\begin{array}{l}0.4 \\
\pm 0.2\end{array}$ \\
\hline $\begin{array}{l}\text { Panlmarin } \\
\text { and Young, } \\
\text { (2019a) }\end{array}$ & HMBR & $\begin{array}{l}52 \\
\pm 32\end{array}$ & ND & $\begin{array}{l}51.0 \\
\pm 45.0\end{array}$ & ND & 177 & $\begin{array}{l}16.0 \\
\pm 4.0\end{array}$ & $\begin{array}{l}144 \\
\pm 17\end{array}$ & $\begin{array}{l}4.0 \\
\pm 2.0\end{array}$ & 6.4 & $\begin{array}{l}2.18 \\
\pm 0.27\end{array}$ & 0.53 & 0.051 \\
\hline
\end{tabular}


greater than $82 \%$. It was also found that the removal rates were the highest during the summer compared to the other seasons, and that the efficiency increased with higher HRT. The GROW constructed wetland provided a solution to greywater treatment without permanent land requirements, and offered medium to high treatment efficiencies. Adrados et al. (2018) evaluated and compared the removal of pathogens in a HFCW and a VFCW for decentralized wastewater treatment in Jutland, Denmark. Microbial indicators, including E. coli, total coliforms, intestinal Enterococci, sulphate-reducing Clostridia, and Bacteroides spp. were monitored every three months for a year. The results demonstrated that all bacterial indicators were significantly reduced in both systems. The VFCW was more effective than the HFCW in its ability to eliminate the evaluated pathogens.

\section{Comparison of the Treatment Performance of Biological Greywater Reclamation Technologies}

The treatment performances of various biological greywater reclamation processes are shown in Table 1. This table shows that the RBC and SBR processes are able to achieve satisfactory performances in regards to the removal of biodegradable organic substances. Since most of the biodegradable organic substances can be removed, the regrowth of microorganisms in the treated water can be avoided, making it more stable for storage over long periods. Furthermore, RBCs and SBRs have similar capital and operating costs in terms of their energy consumption. However, RBCs and SBRs are not able to adequately remove microorganisms, suspended solids, and turbidity. As such, final filtration and disinfection processes are needed to meet the water reuse standards. The combination of an RBC or SBR with a physical filtration and disinfection process is considered to be an economical and feasible solution for greywater recycling. At the present time, UASB bioreactors offer much lower treatment performance than that of an RBC or SBR, even when operated at higher temperatures and HRTs. Due to its poor removal efficiencies of both organic substances and surfactants, the application of the UASB process for greywater treatment is therefore limited.

Constructed wetlands offer great potential for greywater reclamation. Considering their treatment performance, operation requirement, and maintenance cost, constructed wetlands can be regarded as one of the most environmentally friendly and cost-effective technologies for greywater treatment and reuse. However, they require a large space for installation, and may not be suitable for many urban areas. In these situations, MBRs and HMBRs are viable alternatives. These systems offer excellent and consistent effluent quality, the ability to treat greywater with high organic loading rates, a small footprint, and low excess sludge production. As membranes continue to become more affordable, the economic feasibility of MBRbased systems will likely continue to improve in the foreseeable future.

\section{Conclusions}

This study reviewed several of the biological processes currently in development for greywater treatment. Each system offers a variety of advantages and disadvantages, and the selection of a particular biological process for implementation is dependent on the situation at hand. This is because the quality criteria are different for different applications, and the composition and generation rate of greywater varies greatly from one source to another. Thus, regional variability and conditions should be considered during the selection of a treatment process. From this review, it is evident that many researchers have put forth considerable efforts to reduce the cost of biological treatment, and many of these systems may be considered to be viable given today's standards. However, concerns regarding emerging contaminants, such as pharmaceuticals and personal care products, should also be considered prior to the implementation of greywater reclamation, as these compounds may already appear in greywater. Therefore, in accordance with the precautionary principle, future research on the removal of these pollutants should be undertaken as an important step for the development of biological processes for greywater reclamation.

Acknowledgments. This research was supported by the Natural Science and Engineering Research Council of Canada (NSERC), the Canada Foundation for Innovation (CFI), the Canada Research Chairs Program (CRC), the Western Canada Clean Energy Initiative (Project No.: 000015269), and the Petroleum Technology Research Centre.

\section{References}

Abdel-Shafy, H.I., Mansour M.S., and Al-Sulaiman A.M. (2019). Anaerobic/aerobic integration via UASB/enhanced aeration for greywater treatment and unrestricted reuse, Water Practice and Technology. https://doi.org/10.2166/wpt.2019.065

Adrados, B., Arias C. A., Pérez L. M., Codony F., Bécares E., Brix H., and Morató J. (2018). Comparison of removal efficiency of pathogennic microbes in four types of wastewater treatment systems in Denmark, Ecological Engineering, 124: 1-6. https://doi.org/10.10 16/j.ecoleng.2018.09.013

An, C.J., McBean E., Huang G.H., Yao Y., Zhang P., Chen X.J., and Li Y.P. (2016). Multi-Soil-Layering Systems for Wastewater Treatment in Small and Remote Communities, Journal of Environmental Informatics, 27. https://doi.org/10.3808/jei.20 1500328

Atanasova, N., Dalmau M., Comas J., Poch M., Rodriguez-Roda I., and Buttiglieri G. (2017). Optimized MBR for greywater reuse systems in hotel facilities, Journal of Environmental Management, 193: 503-11. https://doi.org/10.1016/j.jenvman.2017.02.041

Baban, A., Hocaoglu S.M., Atasoy E.A., Gunes K., Ayaz S., and Regelsberger M. (2010). Grey water treatment and reuse by using RBC: A kinetic approach, Desalination and Water Treatment, 23: 89-94. https://doi.org/10.5004/dwt.2010.1955

Bani-Melhem, K., and Smith E. (2012). Grey water treatment by a continuous process of an electrocoagulation unit and a submerged membrane bioreactor system, Chemical Engineering Journal, 198: 201-10. https://doi.org/10.1016/j.cej.2012.05.065

Cai, Y.P, Huang, G.H., Nie, X.H., Li, Y.P., and Tan, Q. (2007). Municipal solid waste management under uncertainty: a mixed interval parameter fuzzy-stochastic robust programming approach. Environmental Engineering Science, 24(3), 338-352. https://doi.org /10.1089/ees.2005.0140

Chen, X.J., Huang G., An, C.J., Feng, R.F., Wu, Y.H., and Huang, C. (2019). Plasma-induced PAA-ZnO coated PVDF membrane for oily wastewater treatment: Preparation, optimization, and characterizat - 
ion through Taguchi OA design and synchrotron-based X-ray analysis, Journal of Membrane Science, 582: 70-82. https://doi.org/ 10.1016/j.memsci.2019.03.091

Chen, X.J., Huang, G., An, C.J., Feng, R.F., Yao, Y., Zhao, S., Huang, C., and $\mathrm{Wu}$, Y.H. (2019). Plasma-induced poly (acrylic acid)- $\mathrm{TiO}_{2}$ coated polyvinylidene fluoride membrane for produced water treatment: Synchrotron X-Ray, optimization, and insight studies, Journal of Cleaner Production, 227: 772-83. https://doi.org/10. 1016/j.jclepro.2019.04.226

Chen, X.J., Huang, G., An, C.J., Yao, Y., and Zhao, S. (2018) Emerging $\mathrm{N}$-nitrosamines and $\mathrm{N}$-nitramines from amine-based post-combustion $\mathrm{CO}_{2}$ capture - A review, Chemical Engineering Journal, 335: 921-35. https://doi.org/10.1016/j.cej.2017.11.032

Chen, X.J., Huang, G.H., Fu, H.Y., An, C.J., Yao, Y., Cheng, G.H., and Suo, M.Q. (2017). Allelopathy inhibitory effects of Hydrodictyon reticulatum on Chlorella pyrenoidosa under co-culture and liquorcultured conditions, Water, 9: 416. https://doi.org/10.3390/w9060 416

Chong, S., Sen, T.K., Kayaalp, A., and Ang, H.M. (2012). The performance enhancements of upflow anaerobic sludge blanket (UASB) reactors for domestic sludge treatment - A State-of-the-art review, Water Research, 46: 3434-70. https://doi.org/10.1016/j.wa tres.2012.03.066

Cortez, S., Teixeira, P., Oliveira, R., and Mota, M. (2008). Rotating biological contactors: a review on main factors affecting performance, Reviews in Environmental Science and Bio/Technology, 7: 15572. https://doi.org/10.1007/s11157-008-9127-x

Deng, L., Guo, W., Ngo, H.H., Zhang, J., Liang, S., Xia, S., Zhang, Z., and $\mathrm{Li}, \mathrm{J}$. (2014). A comparison study on membrane fouling in a sponge-submerged membrane bioreactor and a conventional membrane bioreactor, Bioresource Technology, 165: 69-74. https://doi. org/10.1016/j.biortech.2014.02.111

An, D., Liang, H., Li, G.B., Szivak, I., Traber, J., and Pronk, W. (2017). A low energy gravity-driven membrane bioreactor system for grey water treatment: Permeability and removal performance of organics, Journal of Membrane Science, 542: 408-17. https://doi.org/10.101 6/j.memsci.2017.08.037

Elmitwalli, T. A, and Otterpohl, R. (2007). Anaerobic biodegradability and treatment of grey water in upflow anaerobic sludge blanket (UASB) reactor', Water Research, 41: 1379-87. https://doi.org/1 0.1016/j.watres.2006.12.016

Elmitwalli, T., and Otterpohl, R. (2011). Grey water treatment in upflow anaerobic sludge blanket (UASB) reactor at different temperatures, Water Science and Technology, 64: 610-17. https://doi. org/10.2166/wst.2011.616

EPA, US. (1999). Wastewater Technology Fact Sheet-Sequencing Batch Reactors'.

Eriksson, E., Auffarth, K., Henze, M., and Ledin, A. (2002). Characteristics of grey wastewater, Urban water, 4: 85-104. https://doi. org/10.1016/S1462-0758(01)00064-4

Eriksson, E., Yan, X., Lundsbye, M., Madsen, T.S., Andersen, H.R., and Ledin, A. (2007). Variation in grey wastewater quality reused for toilet flushing. In Guiding the growth of water reuse: 6th IWA Specialty Conference on Wastewater Reclamation and Reuse of Sustainability, 9-12 October 2007, Antwerp, Belgium. IWA.

Friedler, E., Kovalio, R., and Galil, N.I. (2005). On-site greywater treatment and reuse in multi-storey buildings, Water Science and Technology, 51: 187-94. https://doi.org/10.2166/wst.2005.0366

Ghaitidak, D.M., and Yadav, K.D. (2013). Characteristics and treatment of greywater-a review, Environmental Science and Pollution Research, 20: 2795-809. https://doi.org/10.1007/s11356-013-1533 $-0$

Ghunmi, L.A., Zeeman, G., Fayyad, M., and van Lier, J.B. (2011). Grey water treatment systems: A review. Critical reviews in environmental science and technology, 41: 657-98. https://doi.org/ $10.1080 / 10643380903048443$
Gross, A., Shmueli, O., Ronen, Z., and Raveh, E. (2007). Recycled vertical flow constructed wetland (RVFCW)-a novel method of recycling greywater for irrigation in small communities and households, Chemosphere, 66: 916-23. https://doi.org/10.1016/j.chemo sphere.2006.06.006

Halalsheh, M., Dalahmeh, S., Sayed, M., Suleiman, W., Shareef, M., Mansour, M., and Safi, M. (2008). Grey water characteristics and treatment options for rural areas in Jordan, Bioresource Technology, 99: 6635-41. https://doi.org/10.1016/j.biorte ch.2007.12.029

Hassard, F., Biddle, J., Cartmell, E., Jefferson, B., Tyrrel, S., and Stephenson, T. (2015). Rotating biological contactors for wastewater treatment-A review, Process Safety and Environmental Protection, 94: 285-306. https://doi.org/10.1016/j.psep.2014.07.003

Hernández Leal, L., Temmink, H., Zeeman, G., and Buisman, C.J. (2010). Comparison of three systems for biological greywater treatment, Water, 2: 155-69. https://doi.org/10.3390/w2020155

Hu, M., Zhang, T., Stansbury, J., Dahab, M., Shi, J., Neal, J., Alahmad, M., Berryman, C., Li, H., and Schwer, A. (2011). Treatment of greywater with shredded-tire biofilters and membrane bioreactors. In World Environmental and Water Resources Congress 2011: Bearing Knowledge for Sustainability, 1877-87. https://doi.org/10. 1061/41173(414)195

Huang, G.H., Cohen, S.J., Yin, Y.Y., and Bass, B. (1996). Incorporation of inexact dynamic optimization with fuzzy relation analysis for integrated climate change impact study. Journal of Environmental Management, 48(1), 45-68. https://doi.org/10.1006/jema. 1996.0065

Huang, G.H., Baetz, B.W., Patry, G.G., and Terluk, V. (1997). Capacity planning for an integrated waste management system under uncertainty: a North American case study. Waste Management \& Research, 15(5), 523-546. https://doi.org/10.1177/0734242X9701500 507

Jamrah, A., Al-Omari, A., Al-Qasem, L., and Ghani, N.A. (2006). Assessment of availability and characteristics of greywater in Amman, Water International, 31: 210-20. https://doi.org/10.108 0/02508060.2 006.9709671

Kassab, G., Halalsheh, M., Klapwijk, A., Fayyad, M., and van Lier, J.B. (2010). Sequential anaerobic-aerobic treatment for domestic wastewater - A review, Bioresource Technology, 101: 3299-310. https://doi.org/10.1016/j.biortech.2009.12.039

Krishnan, V., Ahmad, D., and Jeru, J.B. (2008). Influence of COD: N: $P$ ratio on dark greywater treatment using a sequencing batch reactor, Journal of Chemical Technology \& Biotechnology: International Research in Process, Environmental \& Clean Technology, 83: 75662. https://doi.org/10.1002/jctb. 1842

Kurita, T., Mogi, T., and Kimura, K. (2016). Influence of different biofilm carriers on the operation and membrane fouling of submerged membrane bioreactors, Separation and Purification Technology, 169: 43-49. https://doi.org/10.1016/j.seppur.2016.05.026

Lamine, M., Samaali, D., and Ghrabi, A. (2012). Greywater treatment in a submerged membrane bioreactor with gravitational filtration, Desalination and Water Treatment, 46: 182-87. https://doi.org/10. 1080/19443994.2012.677553

Leal, L.H., Temmink, H., Zeeman, G., and Buisman, C. (2011). Characterization and anaerobic biodegradability of grey water, Desalination, 270: 111-15. https://doi.org/10.1016/j.desal.2010.11. 029

Lettinga, G., and Hulshoff Pol, L.W. (1991). UASB-process design for various types of wastewaters', Water Science and Technology, 24: 87-107. https://doi.org/10.2166/wst.1991.0220

Li, F.Y., Wichmann, K., and Otterpohl, R. (2009). Review of the technological approaches for grey water treatment and reuses, Science of The Total Environment, 407: 3439-49. https://doi.org/ 10.1016/j.scitotenv.2009.02.004

Li, Y.F., Li, Y.P., Huang, G.H., and Chen, X. (2010). Energy and environmental systems planning under uncertainty - an inexact fuzzy- 
stochastic programming approach. Applied Energy, 87(10), 31893211. https://doi.org/10.1016/j.apenergy.2010.02.030

Li, L.P., Zhang, J., Tian, Y., Sun, L., Zuo, W., Li, H., Li, A.R., and Wiesner, M.R. (2019). A novel approach for fouling mitigation in anaerobic-anoxic-oxic membrane bioreactor $\left(\mathrm{A}_{2} \mathrm{O}-\mathrm{MBR}\right)$ by integrating worm predation, Environment International, 127: 615-24. https://doi.org/10.1016/j.envint.2019.02.041

Lim, J.W., Seng, C.E., Lim, P.E., Ng, S.L., and Sujari, A.N.A. (2011) Nitrogen removal in moving bed sequencing batch reactor using polyurethane foam cubes of various sizes as carrier materials, Bioresource Technology, 102: 9876-83. https://doi.org/10.1016/j. biortech.2011.08.014

Li, Z., Gulyas, H., Jahn, M., Gajurel, D.R., and Otterpohl, R. (2004) Greywater treatment by constructed wetlands in combination with TiO2-based photocatalytic oxidation for suburban and rural areas without sewer system, Water Science and Technology, 48: 101-06. https://doi.org/10.2166/wst.2004.0815

Maqsood, I., Huang, G.H, Huang, Y.F, and Chen, B. (2005). ITOM: an interval-parameter two-stage optimization model for stochastic planning of water resources systems. Stochastic Environmental Research and Risk Assessment, 19(2), 125-133. https://doi.org/10. 1007/s00477-004-0220-6

McBean, E. (2019). Removal of Emerging Contaminants: The Next Water Revolution, Journal of Environmental Informatics Letters, 1: 1-7. https://doi.org/10.3808/jeil.201900001

McBean, E., Farrow, C., Preston, T., Yang, A.L., Cheng, H.Y., Wu, Y.C., Liu, Z., Dai, Z.N., Fu, H.Y., and Beauchamp, J. (2019). Investigation of Maintenance Impacts on Flow Rates in Ceramic Disc Water Filters, Journal of Environmental Informatics Letters, 1: 81-86.

Meng, F.G., Zhang, S.Q., Oh, Y., Zhou, Z.B., Shin, H., and Chae, S. (2017). Fouling in membrane bioreactors: An updated review, Water Research,114:151-80. https://doi.org/10.1016/j.watres.2017.02.006

Merz, C., Scheumann, R., Hamouri, B.E., and Kraume, M. (2007). Membrane bioreactor technology for the treatment of greywater from a sports and leisure club, Desalination, 215: 37-43. https://doi. org/10.1016/j.desal.2006.10.026

Murat Hocaoglu, S., Insel, G., Cokgor, E.U., Baban, A., and Orhon, D. (2010). COD fractionation and biodegradation kinetics of segregated domestic wastewater: black and grey water fractions, Journal of Chemical Technology \& Biotechnology, 85: 1241-49. https://doi. org/10.1002/jctb.2423

Nguyen, T., Bui, X., Vo, T., Nguyen, D., Nguyen, P., Do, H., Ngo, H., and Guo, W. (2016). Performance and membrane fouling of two types of laboratory-scale submerged membrane bioreactors for hospital wastewater treatment at low flux condition, Separation and Purification Technology, 165: 123-29. https://doi.org/10.1016/j.sep pur.2016.03.051

Oteng-Peprah, M., Acheampong, M.A., and deVries, N.K. (2018). Greywater Characteristics, Treatment Systems, Reuse Strategies and User Perception-a Review, Water, Air, \& Soil Pollution, 229: 255. https://doi.org/10.1007/s11270-018-3909-8

Ozgun, H., Gimenez, J.B., Ersahin, M.E., Tao, Y., Spanjers, H., and van Lier, J.B. (2015). Impact of membrane addition for effluent extraction on the performance and sludge characteristics of upflow anaerobic sludge blanket reactors treating municipal wastewater, Journal of Membrane Science, 479: 95-104. https://doi.org/10.10 16/j.memsci.2014.12.021

Pathan, A.A., Mahar, R.B., and Ansari, K. (2011). Preliminary study of greywater treatment through rotating biological contactor, Mehran University Research Journal of Engineering and Technology, 30: 531-38.

Pariente, M.I., Siles, J.A., Molina, R., Botas, J.A., Melero, J.A., and Martinez, F. (2013). Treatment of an agrochemical wastewater by integration of heterogeneous catalytic wet hydrogen peroxide oxidation and rotating biological contactors, Chemical Engineering
Journal, 226: 409-15. https://doi.org/10.1016/j.cej.2 013.04.081

Palmarin, M.J., and Young, S. (2019a). Comparison of the treatment performance of a hybrid and conventional membrane bioreactor for greywater reclamation, Journal of Water Process Engineering, 28: 54-59. https://doi.org/10.1016/j.jwpe.2018.12.012

Palmarin, M.J., and Young, S. (2019b). The effects of biocarriers on the mixed liquor characteristics, extracellular polymeric substances, and fouling rates of a hybrid membrane bioreactor, Biochemical Engineering Journal, 141: 278-84. https://doi.org/10.1016/j.bej. 2018.10.027

Ramprasad, C., and Philip, L. (2016). Surfactants and personal care products removal in pilot scale horizontal and vertical flow constructed wetlands while treating greywater, Chemical Engineering Journal, 284: 458-68. https://doi.org/10.101 6/j.cej.2015.08.092

Ramprasad, C., Smith, C.S., Memon, F.A., and Philip, L. (2017). Removal of chemical and microbial contaminants from greywater using a novel constructed wetland: GROW, Ecological Engineering, 106: 55-65. https://doi.org/10.1016/j.ecolen g.2017.05.022

Rojas-Z, U., Fajardo-O, C., Moreno-Andrade, I., and Monroy, O. (2017). Greywater treatment in an aerobic SBR: sludge structure and kinetics, Water Science Technology, 76: 1535-44. https://doi. org/10.2166/wst.2017.341

Saumya, S., Akansha, S., Rinaldo, J., Jayasri, M.A., and Suthindhiran, K. (2015). Construction and evaluation of prototype subsurface flow wetland planted with Heliconia angusta for the treatment of synthetic greywater, Journal of Cleaner Production, 91: 235-40. https://doi.org/10.1016/j.jclepro.2014.12.019

Singh, M., and Srivastava, R.K. (2011). Sequencing batch reactor technology for biological wastewater treatment: a review, AsiaPacific Journal of Chemical Engineering, 6: 3-13. https://doi.org /10.1002/apj.490

Sklarz, M.Y., Gross, A., Yakirevich, A., and Soares, M. (2009). A recirculating vertical flow constructed wetland for the treatment of domestic wastewater, Desalination, 246: 617-24. https://doi.org/ 10.1016/j.desal.2008.09.002

Song, P., Huang, G.H., An, C.J., Shen, J., Zhang, P., Chen, X.J., Shen, J., Yao, Y., Zheng, R.B., and Sun, C.X. (2018). Treatment of rural domestic wastewater using multi-soil-layering systems: Performace evaluation, factorial analysis and numerical modeling, Science of The Total Environment, 644: 536-46. https://doi.org/10.1016/j.scito tenv.2018.06.331

Sun, J.Y., Liang, P., Yan, X.X., Zuo, K.C., Xiao, K., Xia, J.L., Qiu, Y., Wu, Q., Wu, S.J., Huang, X., Qi, M., and Wen, X.H. (2016). Reducing aeration energy consumption in a large-scale membrane bioreactor: Process simulation and engineering application, Water Research, 93: 205-13. https://doi.org/10.1016/j.watres.2016.02.026

Tabraiz, S., Haydar, S., and Hussain, G. (2016). Evaluation of a costeffective and energy-efficient disc material for rotating biological contactors (RBC), and performance evaluation under varying condition of RPM and submergence, Desalination and Water Treatment, 57: 20439-46. https://doi.org/10.1080/1944399 4.2015.1113143

Tan, Q., Huang, G.H., and Cai, Y.P. (2011). Radial interval chanceconstrained programming for agricultural non-point source water pollution control under uncertainty. Agricultural Water Management, 98(10), 1595-1606. https://doi.org/10.1016/j.agwat.2011.05. 013

Tombola, R., Buttiglieri, G., Auset, M., and Gonzalez-Olmos, R. (2019). Recycled corrugated wire hose cover as biological carriers for greywater treatment in a sequential batch biofilm reactor, Journal of Environmental Management, 240: 475-84. https://doi.org /10. 1016/j.jenvman.2019.02.116

Vuppaladadiyam, A.K., Merayo, N., Prinsen, P., Luque, R., Blanco, A., and Zhao, M. (2019). A review on greywater reuse: quality, risks, barriers and global scenarios, Reviews in Environmental Science and Bio/Technology, 18: 77-99. https://doi.org/10.1007/s1 1157018-9487-9 
Waskar, V.G., Kulkarni, G.S., and Kore, V.S. (2012). Review on process, application and performance of rotating biological contactor (RBC), International Journal of Science and Research Publications, 2: 1-6.

Weng, S.Q., Huang, G.H., and Li, Y.P. (2010). An integrated scenariobased multi-criteria decision support system for water resources management and planning-A case study in the Haihe River Basin. Expert Systems with Applications, 37(12), 8242-8254. https://doi. org/10.1016/j.eswa.2010.05.061

Wu, B. (2019). Membrane-based technology in greywater reclamation: A review, Science of The Total Environment, 656: 184-200. https:// doi.org/10.1016/j.scitotenv.2018.11.347

Wu, S.M., Huang, G.H., and Guo, H.C. (1997). An interactive inexactfuzzy approach for multiobjective planning of water resource systems. Water Science and Technology, 36(5), 235-242. https:// doi.org/10.1016/S0273-1223(97)00479-4

Wu, S.B., Carvalho, P.N., Müller, J.A., Manoj, V.R., and Dong, R.J. (2016). Sanitation in constructed wetlands: A review on the removal of human pathogens and fecal indicators, Science of The Total Environment, 541: 8-22. https://doi.org/10.1016/j.scitotenv.2015.09. 047

Young, S., and Xu, A. (2008). Development and testing of a low sludge discharge membrane bioreactor for greywater reclamation, Journal of Environmental Engineering and Science, 7: 423-31. https://doi. org/10.1139/S08-015

Yu, H., Huang, G.H., An, C.J., and Wei, J. (2011). Combined effects of DOM extracted from site soil/compost and biosurfactant on the sorption and desorption of PAHs in a soil-water system. Journal of Hazardous Materials, 190(1-3), 883-890. https://doi.org/10.1016/ j.jhazmat.2011.04.026

Zha, X., Ma, J., and Lu, X.W. (2018). Performance of a coupling device combined energy-efficient rotating biological contactors with anoxic filter for low-strength rural wastewater treatment', Journal of Cleaner Production, 196: 1106-15. https://doi.org/10.1016/j.jcle pro.2018.06.138

Zhang, P., Huang, G.H., An, C.J., Fu, H.Y., Gao, P.F., Yao, Y., and Chen, X.J. (2019). An integrated gravity-driven ecological bed for wastewater treatment in subtropical regions: Process design, performance analysis, and greenhouse gas emissions assessment, Journal of Cleaner Production, 212: 1143-53. https://doi.org/10.1 016/j.jclepro.2018.12.027

Zhao, S., Huang, G.H., Mu, S., An, C.J., and Chen, X.J. (2017) Immobilization of phenanthrene onto gemini surfactant modified sepiolite at solid/aqueous interface: Equilibrium, thermodynamic and kinetic studies, Science of The Total Environment, 598: 619-27. https://doi.org/10.1016/j.scitotenv.2017.04.120 